\title{
Effects of different mulch types on soil moisture content in potted shrubs
}

\author{
S Stelli ${ }^{1,2 *}$, L Hoy $^{1,2}$, R Hendrick $^{2}$ and M Taylor ${ }^{2}$ \\ 'Environmental Management Services, Rand Water, PO Box 1127, Johannesburg, 2000, South Africa \\ ${ }^{2}$ Applied Behavioural Ecology \& Ecosystem Research Unit, University of South Africa, PO Box 392, UNISA, 0003, South Africa
}

\begin{abstract}
South Africa is classified as a semi-arid environment with limited natural water resources and variable rainfall. It is also described as water scarce, with many of its water resources already fully exploited. Gardening is one of the principal methods that people use to experience nature, and gardens can also be a public demonstration of personal value, a source of satisfaction, and part of a connection to the community. However, gardens are also one of the top users of water, accounting for approximately $31-50 \%$ of potable water supplied for domestic and urban use. In order to reduce the amount of water used in gardens, water conservation strategies such as mulching need to be employed. In view of South Africa's water situation, it is Rand Water's aim to promote the wise use of water, in all aspects of water consumption. It is anticipated that this study will provide information useful to water saving in urban gardens and landscapes, and will promote the use of mulch amongst gardeners, landscapers and the general public. Mulching potted plants with various organic and inorganic mulch was found to conserve an average of $35 \%$ more soil water content over approximately 6 weeks of no irrigation than plants with no mulch. Mulch was shown to increase plant health and vitality, as indicated by stomatal conductance, by an average of $44 \%$ than plants with no mulch. The recommended mulch type for use in gardens is bark chips in both summer and winter seasons.
\end{abstract}

Keywords: mulch, soil moisture content, urban gardens, water, water conservation

\section{INTRODUCTION}

South Africa falls within a semi-arid region, and receives an average of $492 \mathrm{~mm}$ of annual rainfall (Schulze, 1997). The country is faced with widely ranging precipitation patterns, uneven rainfall distribution and high evaporation rates. The mean annual pan evaporation ranges from $4000 \mathrm{~mm}$ in the Upington area, to $2000-2500 \mathrm{~mm}$ in Gauteng (Tyson, 1986); evaporation exceeds rainfall throughout the country. The International Water Management Institute estimates that South Africa will experience physical water scarcity by 2025 , with an annual freshwater availability of less than $1000 \mathrm{~m}^{3}$ per capita (Otieno and Ochieng, 2004). Careful and efficient use of water is essential, especially in a water-stressed country such as South Africa, where available water per capita is currently between 1000 and $1700 \mathrm{~m}^{3} \cdot \mathrm{yr}^{-1}$ (DWA, 2013).

Rand Water is Africa's largest potable bulk water supplier, and was established in 1903 in response to the demand for water in the rapidly expanding city of Johannesburg. The drought of 1995 created a need for water awareness and conservation in Rand Water's area of supply, and Rand Water's environmental brand 'Water Wise' was initiated as a result. Water Wise consists of environmental educators, researchers, trainers, and community liaison partners that work with end-users to inform and educate the general public on South Africa's water situation. Water Wise and Research (WW\&R) is a branch of the brand that focuses on awareness amongst the adult market, and water conservation and environmental research (Hoy, 2013).

Gauteng makes up the largest part of Rand Water's area of supply; thus many of the research projects managed by WW\&R focus on work within this area. This study was conducted on-site at Rand Water's Environmental Management Services Nursery, situated in the south of Johannesburg. According

\footnotetext{
To whom all correspondence should be addressed.

Iif 0117249371 ;

e-mail: sstelli@randwater.co.za
}

Received 8 December 2016; accepted in revised form 18 June 2018 to the Köppen-Geiger climate type map of Africa (Peel et al., 2007), Johannesburg is classified as Cwb, namely warm temperate, with warm summers and dry winters. Johannesburg falls within the mesic highveld grassland bioregion $(\mathrm{Gm})$, which has a mean annual precipitation (MAP) of $726 \mathrm{~mm}$, a mean annual potential evaporation (MAPE) value of $1958 \mathrm{~mm}$ and a mean annual soil moisture stress (MASMS) value of $74 \%$ (Mucina et al., 2006). This data indicates that the region experiences approximately 270 days a year where evaporative demand exceeds soil moisture supply. The mesic highveld grassland is the largest bioregion within the grassland biome and has the highest number of vegetation types (Mucina et al., 2006). Most of Rand Water's area of supply falls within this biome. The average rainfall, taken over a 30 -year period for the Rand Water supply area, is $654.25 \mathrm{~mm}$.

Although Johannesburg was originally a grassland habitat, there are now an estimated 4.8 million trees planted in private gardens across the city (City of Johannesburg, n.d.). Gardening is one of the principal means by which people experience nature, and gardens are a public demonstration of personal values, a source of satisfaction, and part of a connection to the community (Clayton, 2007). In the domestic sector, water use has increased by 5 to $27 \%$ over the past 10 years (DWA, 2013) and water use in gardens accounts for approximately $31-50 \%$ of water supplied for domestic and urban use (Water Wise Gardening, n.d.). Water is one of our most valuable natural resources (Wiese, 1999). The implementation of Water Wise practises in the garden, mulching included, can reduce water use by $10-32 \%$ (Water Wise Gardening, n.d.).

Many studies focus on the use of mulch in agricultural systems (Allison, 1973; Gaur and Mukeherjee, 1980; Monks et al., 1997; Olasantan, 1999; Tolk et al., 1999; Adekalu et al., 2006; Sarkar and Singh, 2007; Głąb and Kulig, 2008; OrtizCeballos and Fragoso, 2003; Campiglia et al., 2010; Fang et al., 2010; Kumar and Dey, 2011). Mulching is an effective cropping method that is used widely in annual and perennial crops for saving water and increasing soil temperature (Zegada-Lizarazu and Berliner, 2011), as well as improving crop performance 
and weed control (Campiglia et al., 2010). A literature review established that mulch application in gardening and recreational or landscape horticulture is extensively discussed in gardening forums, and on nursery and garden centre websites. The use of mulch in managed landscapes is increasing rapidly (Herms et al., 2001). There is, however, a gap in knowledge, specifically in peer-reviewed journals, of the application of mulch to gardens and recreational landscapes. This study aims to contribute towards filling this gap by focusing on the use of mulch in potted shrubs as a water-saving gardening practice. In this document, recreational gardens are defined as those owned and maintained by homeowners, while industrial gardens and landscapes are defined as those found in office parks and at business premises.

There are benefits to the use and the application of specific types of mulch that depends on the requirements of the garden, landscape or crop. For example, a study on the comparison of decomposition properties of different types of mulch showed that cypress bark, pine bark and pine needle mulch decayed at a much slower rate than eucalyptus bark mulch. However, pine and cypress bark mulch were shown to cause acidity in soils to increase (Duryea et al., 1999). Compost used as mulch can improve the fertility and nutrient status of soil; however, it does not significantly reduce the effect of water erosion on soil (Arthur et al., 2011). The effect of different types of mulches may be attributed to their inherent characteristics such as their resistance to decomposition, structure and particle size and shape (Omoro and Nair, 1993). Gupta (1991) showed that application of organic mulch to 10 tree species increased tree survival by as much as $37 \%$, as well as increased plant height, total aboveground biomass, and root biomass.

According to the Colorado State University, using mulch reduces evaporation of water from soil, and can reduce irrigation needs by up to $50 \%$ (Neibauer and Waskom, 2004). The use of mulch in the garden can thus potentially save the gardener large quantities of water and substantial costs. The application of mulch to soil improves the physical conditions, chemical environment and biological activities of soil. Soil physical properties include water infiltration, retention and percolation capacity, soil aeration and mechanical conditions of soil (Stigter, 1984). The main advantage of mulching is organic and nutrient supply (Głąb and Kulig, 2008). For example, an addition of a layer of $15 \mathrm{~cm}$ of leaf mulch can increase organic matter as well as phosphorus, magnesium and cation exchange capacity in the soil (Athy et al., 2006). The organic carbon, total nitrogen and available phosphorus content of soils can be increased with the addition of mulch (Gaur and Mukherjee, 1980). Mulching influences the soil moisture regime (Zegada-Lizarazu and Berliner, 2011) by controlling evaporation from the soil surface, improving infiltration and soil-moisture retention, and facilitating condensation of water at night due to temperature reversals (Acharya et al., 2005). Soil moisture content is increased in mulched soil in comparison to un-mulched soils, due to reduced evaporation losses from the soil surface (Gaur and Mukherjee, 1980; Olasantan, 1999). Mulch also enhances water use efficiency (Sarkar and Singh, 2007), while significantly increasing available water capacity and total porosity. Soil is protected by mulch from water erosion by the reduction of the impact of raindrops, while organic residue can also slow surface run-off and increase infiltration (Mulumba and Lal, 2008).
Water use efficiency (WUE) is analogous to an investment strategy for the plant, and is defined as the rate of photosynthesis to transpiration. Thus, optimal stomata aperture size will be defined as the one where WUE is maximized under environmental conditions (Swarthout, 2012). WUE is often used as a functional indicator of plant growth and health under water-deficit conditions (Rahimi et al., 2013). Studies have shown that WUE improves at mild soil water deficits and then declines dramatically as the soil dries (Liu et al., 2005). Usually, under mild drought stress WUE will initially increase as stomatal conductance decreases, in response to a lower reduction in photosynthesis as compared to transpiration. Under severe drought stress, WUE will decrease as stomatal conductance decreases when the reduction in the rate of photosynthesis is larger than the reduction in transpiration (Swarthout, 2012).

The growth, survival and photosynthesis of plants from semi-arid regions is highly affected by water stress as a result of water deficits, which are associated with high temperatures and high light stress (Chaves et al., 2002). In order to conserve water, nutrients and carbohydrates, plants respond to stresses such as soil drying by closing stomatal pores (Wilkinson and Davies, 2002). Studies have shown that the response of stomata is linked more closely to soil moisture content than leaf water status, indicating that stomata may be responding to chemical signals produced by dehydrating roots (Chaves et al., 2002). Zajicek and Heilman (1991) suggest that mulched cultivars will have a higher daytime stomatal conductance than those on bare soil and turf grass surfaces. Montague et al. (2007) have shown how stomatal conductance in newly transplanted shrubs is greater when plants are mulched.

In a survey conducted by Rand Water at various nurseries and garden centres in Gauteng, 36\% of the participants $(n=373)$ stated that they apply mulch as a treatment to their gardens all the time to reduce water loss (Quest, 2011). This indicates that a relatively large percentage of homeowners with gardens use mulch, as well as a fair percentage of Green Industry members. This study investigated the aspect of watersaving potential of mulch on plants.

\section{Research aim}

The main aim of this research was to investigate the effectiveness of various mulch types in conserving soil moisture. The common garden shrub, Polygala myrtifolia, was used for this study. P. myrtifolia was chosen as a study species as it fulfilled the following requirements:

- The plant is readily available from local nurseries and garden centres. This information was obtained by conducting a telephonic survey with various nurseries and garden centres in Gauteng $(n=9)$.

- It is not a 'spreading' plant, in that its growth form is that of a small, upright perennial shrub, suitable for growth in containers.

- Based on anecdotal evidence gleaned from the Green Industry professionals via telephonic surveys, this plant is categorized as a low- to medium-water-use plant.

- It is an indigenous species that is easy to grow in gardens and landscapes, and is also propagated by the EMS Nursery.

In order to fulfil the aim, the following objectives were defined:

- To compare the effectiveness of selected mulch types on soil moisture conservation

- To determine the effectiveness of selected mulch types on the health of plants

- To observe soil moisture levels in container shrubs over two seasons 


\section{MATERIALS AND METHODS}

\section{Site}

This study was conducted inside Hothouse 2, situated at Rand Water Environmental Management Services (EMS) Nursery $\left(26^{\circ} 21^{\prime} 08^{\prime \prime S} ; 28^{\circ} 04^{\prime} 02^{\prime \prime}\right.$ ) over June/July/August 2013 and November/December 2013. Climate data during the study periods were recorded with the site's own weather station Campbell Scientific CR10x, which records cumulative rainfall, humidity, wind speed, wind direction and temperature. Mean temperature during the months of June, July and August 2013 (winter trial) was $9.53^{\circ} \mathrm{C}$ and $20.2^{\circ} \mathrm{C}$ during the months of November and December 2013 (summer trial).

The hothouse has clear corrugated fibreglass sheeting for the walls and opaque sheeting for the roof. The sheeting allows $50-85 \%$ of light transmission and $50-80 \%$ heat transmission, depending on the colour of the fibreglass. It is north-facing and $6 \mathrm{~m} \mathrm{x} 10 \mathrm{~m}$ in size $\left(60 \mathrm{~m}^{2}\right)$. There is a slight slope to the floor of the hothouse to allow for effective drainage.

\section{Mulch type investigative study}

Different types of mulch were selected for use based on a preliminary investigation into the most popular and widely used mulches by gardeners, landscapers, horticulturists, garden centres and nurseries in Gauteng. The aim of this was to use products that are actually used and sold within the Green Industry.

From the 9 responses, a total of 16 suggestions on commonly used or purchased or popular mulch were supplied. Results show that the majority of mulch sold and used is organic (75\%), followed by inorganic (25\%). Only one mention was made of using living ground covers as mulch and this sug gestion was made by a self-employed horticulturist. The most commonly used organic mulch type is bark/wood chips (43\%), followed by leaves (14\%) and compost (14\%), while the only

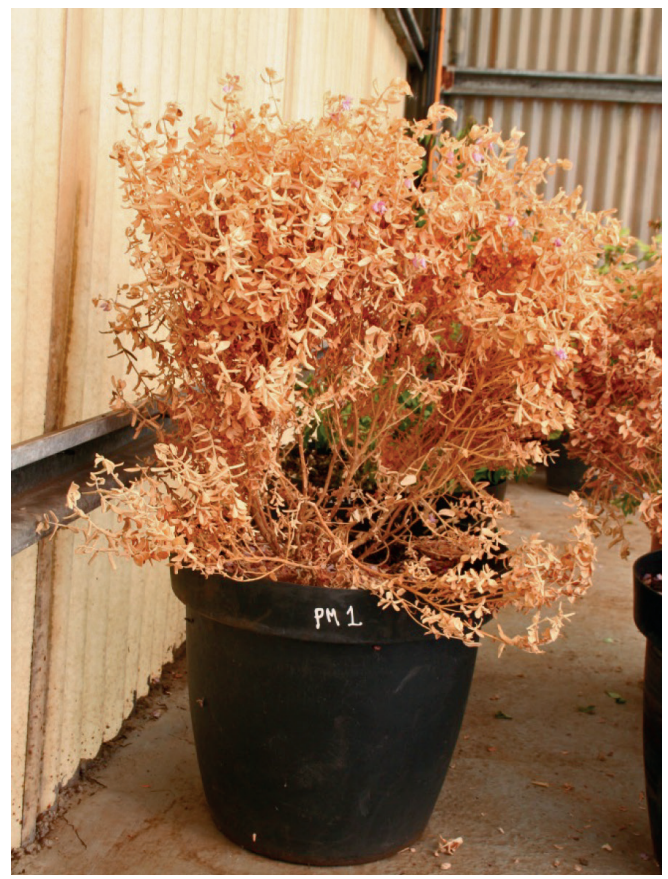

Figure 1

Example of P. myrtifolia shrub that no longer showed stomatal conductance readings and was presumed dead inorganic mulch types mentioned were pebbles or gravel (22\%). No mention was made of the use of newspaper or plastic sheeting as mulch, even though this type of mulch is referred to in literature on crop mulches (e.g. Ashworth and Harrison, 1983; Kumar and Dey, 2011; Zegada-Lizarazu and Berliner, 2011).

From the results of the preliminary study it was decided that $75 \%$ of the mulch used in the project would be organic (bark chips, compost, and garden waste such as leaves or grass cuttings), while $25 \%$ would be inorganic (medium-sized pebbles). Mulch was not dug into the soil (following Wiese, 1999). Mulch was placed at the recommended thickness that promotes water conservation, as per Wiese (1999), as it is assumed that this would be practised by gardeners and landscapers that intend to use mulch effectively.

\section{Pilot study}

A pilot study was conducted in order to establish the duration for which P. myrtifolia shrubs can remain alive, i.e., still displaying signs of stomatal conductance, without having water applied under controlled, indoor conditions. Five mature P. myrtifolia shrubs were re-planted into sterilized plastic $36 \mathrm{~L}$ pots, using commercial potting soil. The shrubs were placed in the hothouse and watered regularly (hand watering with a hose, 3 times a week as per Rand Water Nursery standards) during the 6 -week establishment period. After 6 weeks, watering ceased and plants were left un-watered and un-mulched for the duration of the pilot study.

From Day 1 of the pilot study (first day after cessation of watering) data recording was done every second day at the same time (13:00), for stomatal conductance (SC) and soil water content (SWC), for each plant. Recording of SC was done with a Decagon SC-1 Leaf Porometer, while SWC was measured with The Campbell Scientific HydroSense Soil Water Measurement System (CD620, CS620). Measurements were taken daily until both stomatal conductance and volumetric soil moisture content readings were zero. It was assumed at this stage that the plants were dead (Fig. 1).

\section{Experimental design}

Two separate trials were run to account for ambient temperature variations, one during the winter season (June-August 2013) and one during the summer season (November - December 2013). Each pair of trials was designed and set up as exact replicas. Ninety black plastic pots (36 L) with drainage holes were sterilized using a Jeyes Fluid and water solution of 1:8 (Hoy, 2011). Polygala myrtifolia (September bush) (Fig. 2) plants of approximately $1.5 \mathrm{~m}$ in height were planted individually in the pots using Culterra potting soil that had been sent for analysis at the Agricultural Research Council (ARC) (Table 1).

All potting soil was sourced from the same supplier; thus consistency in soil elements and characteristics was assumed. All plants were sourced from the same supplier to ensure genetic consistency and to prevent the spread of disease. Once plants were potted out, they were placed in the hothouse for an establishment or settling period of 6 weeks, as per industry standard (Hoy, 2013). Plants were watered and fertilized according to Rand Water EMS Nursery standards for the duration of the establishment period.

The experimental design consisted of a randomized complete block design, which was made up of 4 treatments, 1 control, and 18 replicates per treatment and control. One shrub was planted per pot. Ninety (90) physically similar 


\begin{tabular}{|c|c|}
\hline \multicolumn{2}{|c|}{$\begin{array}{c}\text { TABLE } 1 \\
\text { Growth media analysis of Culterra potting soil }\end{array}$} \\
\hline Parameter & Mean \pm SE \\
\hline Moisture \% & $39.70 \pm 0.62$ \\
\hline $\mathrm{pH}$ & $5.97 \pm 0.07$ \\
\hline Electrical conductivity $\left(\mathrm{mS} \cdot \mathrm{m}^{-1}\right)$ & $157.50 \pm 4.75$ \\
\hline $\mathrm{NO}_{3}^{-1}\left(\mathrm{mg} \cdot \mathrm{L}^{-1}\right)$ (nitrates) & $123.65 \pm 38.2$ \\
\hline $\mathrm{NO}_{2}^{-1}\left(\mathrm{mg} \cdot \mathrm{L}^{-1}\right)$ (nitrites) & $13.01 \pm 3.74$ \\
\hline $\mathrm{Cl}^{-1}\left(\mathrm{mg} \cdot \mathrm{L}^{-1}\right)$ (chloride) & $175.81 \pm 13.8$ \\
\hline $\mathrm{F}^{-1}\left(\mathrm{mg} \cdot \mathrm{L}^{-1}\right)$ (fluoride) & $6.14 \pm 0.95$ \\
\hline $\mathrm{SO}_{4}^{-2}\left(\mathrm{mg} \cdot \mathrm{L}^{-1}\right)$ (sulphates) & $491.15 \pm 15.3$ \\
\hline $\mathrm{PO}_{4}^{-3}\left(\mathrm{mg} \cdot \mathrm{L}^{-1}\right)$ (phosphates) & $136.83 \pm 6.50$ \\
\hline $\mathrm{Na}\left(\mathrm{mg} \cdot \mathrm{L}^{-1}\right)$ (sodium) & $78.65 \pm 1.90$ \\
\hline $\mathrm{K}\left(\mathrm{mg} \cdot \mathrm{L}^{-1}\right)$ (potassium) & $606.29 \pm 12.2$ \\
\hline $\mathrm{Ca}\left(\mathrm{mg} \cdot \mathrm{L}^{-1}\right)($ calcium$)$ & $136.67 \pm 8.71$ \\
\hline $\operatorname{Mg}\left(\mathrm{mg} \cdot \mathrm{L}^{-1}\right)($ magnesium$)$ & $68.10 \pm 5.08$ \\
\hline $\mathrm{B}\left(\mathrm{mg} \cdot \mathrm{L}^{-1}\right)$ (boron) & $0.15 \pm 0.03$ \\
\hline $\mathrm{Fe}\left(\mathrm{mg} \cdot \mathrm{L}^{-1}\right)$ (iron) & $0.00 \pm 0.00$ \\
\hline Mn (mg. $\left.\mathrm{L}^{-1}\right)$ (manganese) & $0.13 \pm 0.04$ \\
\hline $\mathrm{Cu}\left(\mathrm{mg} \cdot \mathrm{L}^{-1}\right)$ (copper) & $0.00 \pm 0.00$ \\
\hline $\mathrm{Zn}\left(\mathrm{mg} \cdot \mathrm{L}^{-1}\right)(\mathrm{zinc})$ & $0.05 \pm 0.05$ \\
\hline Bulk density & $0.50 \pm 0.02$ \\
\hline Water holding capacity & $56.22 \pm 0.69$ \\
\hline Air porosity & $10.59 \pm 0.46$ \\
\hline
\end{tabular}

\begin{tabular}{|c|c|c|c|}
\hline \multicolumn{4}{|c|}{$\begin{array}{c}\text { TABLE } 2 \\
\text { Weekly irrigation schedule for Gauteng-based urban } \\
\text { gardens based on hydro zones }\end{array}$} \\
\hline Season & High zone & Medium zone & Low zone \\
\hline Summer & $25 \mathrm{~mm}(100 \%)$ & $15 \mathrm{~mm}(60 \%)$ & $12 \mathrm{~mm}(50 \%)$ \\
\hline $\begin{array}{l}\text { Spring/ } \\
\text { Autumn }\end{array}$ & $15 \mathrm{~mm}(60 \%)$ & $12 \mathrm{~mm}(50 \%)$ & $7 \mathrm{~mm}(25 \%)$ \\
\hline Winter & $12 \mathrm{~mm}(50 \%)$ & 7 mm (25\%) & $\begin{array}{l}12 \mathrm{~mm} \text { (every } \\
2^{\text {nd }} \text { week) }\end{array}$ \\
\hline
\end{tabular}

For the second trial, each plant was watered once-off by hand with $25 \mathrm{~mm}$ of water, as per the industry standard (Hoy, 2013) (Table 2) for a medium-water-use plant in summer. Trial 2 was run from 05 November 2013 to 12 December 2013 (37 days).

For both trials, immediately after watering, plants were mulched according to a randomized complete block design. Four types of mulch were used, namely, bark chips, dead leaves, white pebbles, and compost, in addition to the control plants with no mulch. Therefore, each mulch type and the control were randomly assigned to 18 plants. Thereafter, plants were kept in a controlled environment (Hothouse 2) with no irrigation or access to any water or rainfall.

SWC and SC readings were taken for each shrub simultaneously. SWC (\%) was taken with The Campbell Scientific HydroSense Soil Water Measurement System (CD620, CS620) by fully inserting the two $20 \mathrm{~cm}$ probes into the soil midway between the main stem of the shrub and the outer diameter of the pot. Where possible, readings were taken at the same point in each pot throughout each trial. $\mathrm{SC}\left(\mathrm{mmol} \cdot \mathrm{m}^{-2} \cdot \mathrm{s}^{-1}\right)$ measurements were taken abaxially with Decagon SC-1 Leaf Porometer by placing the sensor head over a suitably-sized leaf and measuring readings for $30 \mathrm{~s}$ with the automatic mode facility. Data were recorded from 13:00-15:00 every Monday and Thursday for a period of 6 weeks, for both trials. Readings were taken from 13:00-15:00 every day, due to research that shows plants are relatively stable in terms of water flux and water status for about an hour or two after solar noon (Blum, 2011).

No fertilizer was added to the plants during the research. This was an attempt to reduce the effect of added minerals and nutrients on the health of the plant.

A number of assumptions were made when analysing the data. Firstly, that ambient temperatures in the hothouse will be slightly higher than outdoors. This is due to the greenhouse effect created by the hothouse environment. Hothouses are designed to take full advantage of solar heat to ensure that daytime requirements for heating are met during much of the year (Macdonald, 1986). Also, it was assumed that the potting soil was homogenous across all replicates and that plants were genetically similar, as they were sourced from the same supplier.

The effects of mulch when used in the hothouse will be different to that when used outdoors in landscapes and gardens. For example, plants will not be exposed to frost in the hothouse. Temperatures experienced in the hothouse may be higher than outdoors. The effect of wind will be decreased and the effect of natural precipitation will be removed. No direct sunlight will be received by the soil/ mulch in the pots. The results of this study can be cautiously extrapolated to outdoor environments if it is assumed that the soil in a container is exposed to more heat and drying than soil in a garden, and therefore if mulch retains soil 
moisture in a container it will most likely do so in a garden situation (Hoy, 2013).

\section{Statistical analyses}

The difference in SWC and SC between different treatments and the control within each trial was analysed using oneway ANOVAs and post-hoc Tukey Studentized Range tests $(a, P=0.05)$. The difference in SWC and SC between trials was analysed using unpaired independent Student $t$-tests. The relationship between SWC content and SC within trials was described by one-way regressions. Data are presented as means \pm standard errors (SE) unless otherwise stated. The programmes Microsoft Excel 2010 and IBM SPSS Statistics 21 were used for all statistical analyses.

\section{RESULTS}

Trial 1 was run over the winter season in Gauteng. Results from one-way ANOVA analysis showed that there was a significant difference between mulch types for SC $(P<0.05 ; F=3.14$; d.f. $=4.1165)$, where un-mulched shrubs had a significantly lower mean SC than any of the mulched shrubs (Table 3). Shrubs mulched with bark chips had the highest mean SC, followed by white pebbles, dry leaves, and compost (Table 3 ).

There was a significant difference in SWC between the mulch types $(P<0.05 ; F=5.73$; d.f. $=4.1165)$. Shrubs with no mulch (control) had a significantly lower SWC than shrubs mulched with any of the other types of mulch (Table 3). Shrubs mulched with bark chips had a slightly higher mean SWC than shrubs mulched with dry leaves, followed by white pebbles, and lastly compost (Table 3 ).

For Trial 1, SWC decreased from $19.83 \pm 1.23 \%$ for all shrubs on Day 1, to $4.87 \pm 1.19 \%$ on Day 43 (Fig. 3). Therefore, SWC decreased by $75 \%$ over 42 days with no watering, except on Day 1. The outlier value on Day 41 is attributed to accidental over-spray from watering conducted in the adjoining hothouse.

SC measures of shrubs decreased by $80.5 \%$ from Day 1 $\left(68.23 \pm 0.96 \mathrm{mmol} \cdot \mathrm{m}^{-2} \cdot \mathrm{s}^{-1}\right)$, when they were last watered, over 37 days to the last day of the trial $\left(13.28 \pm 5.35 \mathrm{mmol} \cdot \mathrm{m}^{-2} \cdot \mathrm{s}^{-1}\right)$ (Fig. 4). Mean SC increased slightly from Day 4 to Day 5 for shrubs mulched with bark chips, dry leaves and white pebbles (Fig. 4).

Trial 2 ran during Gauteng's summer season. Results from one-way ANOVA analysis showed that there was a significant

\begin{tabular}{|c|c|c|}
\hline \multicolumn{3}{|c|}{$\begin{array}{c}\text { TABLE } 3 \\
\text { One-way ANOVA results }(P \text { - value; } F \text {-value) for the } \\
\text { comparison between mulch types within Trial } 1 \text { for } \\
\text { stomatal conductance (mean } \pm S E ; n=234 \text { ) and soil } \\
\text { water content (mean } \pm S E ; n=234)\end{array}$} \\
\hline \multirow{2}{*}{ Mulch type } & $\begin{array}{l}\text { Stomatal conductance } \\
\left(\mathrm{mmol} \cdot \mathrm{m}^{-2} \cdot \mathrm{s}^{-1}\right)\end{array}$ & $\begin{array}{l}\text { Soil water } \\
\text { content (\%) }\end{array}$ \\
\hline & \multicolumn{2}{|c|}{ Mean \pm SE } \\
\hline Bark chips & $55.79 \pm 6.15$ & $12.17 \pm 0.53$ \\
\hline Compost & $43.99 \pm 2.15$ & $10.57 \pm 0.51$ \\
\hline Dry leaves & $44.89 \pm 2.48$ & $12.42 \pm 0.59$ \\
\hline No mulch (control) & $39.21 \pm 2.21$ & $9.34 \pm 0.59$ \\
\hline White pebbles & $48.21 \pm 2.61$ & $10.42 \pm 0.46$ \\
\hline$F$ & 3.14 & 5.73 \\
\hline$P$ & 0.014 & 0.0001 \\
\hline
\end{tabular}

difference between compost and pebbles for SC $(P<0.05$; $F=3.12$; d.f. $=4.1165)$, where shrubs mulched with pebbles had a significantly higher SC than those mulched with compost (Table 4). SC then decreased non-significantly with bark chips, followed by dry leaves, and no mulch (Table 4).

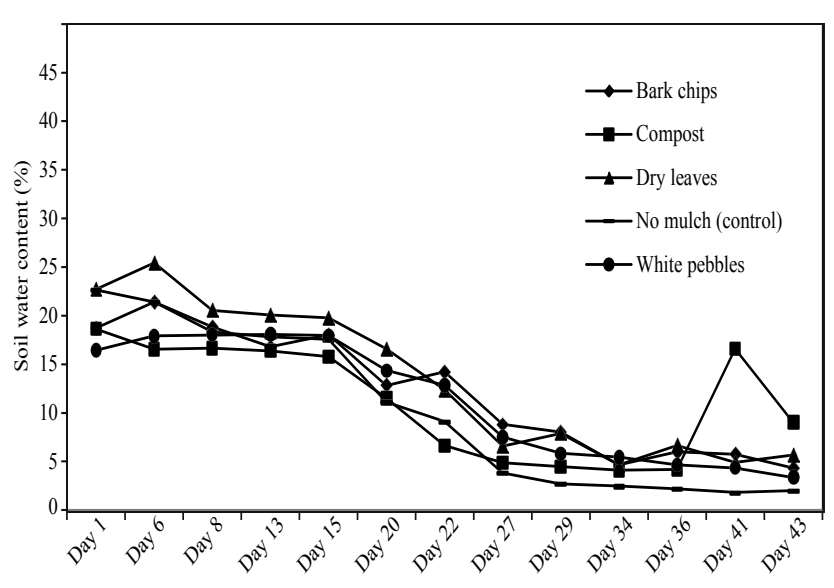

Figure 3

Soil water content over time for P. myrtifolia shrubs $(n=90)$ mulched with different types of mulch in Trial 1 (cold winter season)

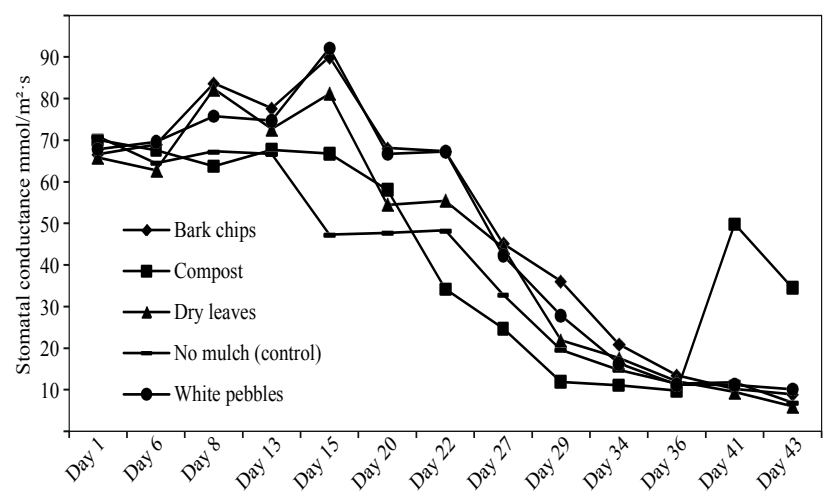

Figure 4

Stomatal conductance over time for P. myrtifolia shrubs $(n=90)$ mulched with different types of mulch in Trial 1 (cold winter season)

\begin{tabular}{|l|c|c|}
\hline \multicolumn{3}{|c|}{ TABLE 4 } \\
$\begin{array}{c}\text { One-way ANOVA results (P-value; F-value) for the } \\
\text { comparison between mulch types within Trial } 2 \text { for } \\
\text { stomatal conductance (mean } \pm \text { SE; } \boldsymbol{n}=234 \text { ) and } \\
\text { soil water content (mean } \pm \text { SE; } \boldsymbol{n}=234)\end{array}$ \\
\hline \multirow{2}{*}{ Mulch type } & $\begin{array}{c}\text { Stomatal } \\
\text { conductance } \\
\left(\text { mmol }^{-2} \mathbf{-}^{-1} \text { ) }\right.\end{array}$ & $\begin{array}{c}\text { Soil water } \\
\text { content (\%) }\end{array}$ \\
\cline { 2 - 3 } & \multicolumn{2}{|c|}{ Mean \pm SE } \\
\hline Bark chips & $7.39 \pm 1.0$ & $2.57 \pm 0.22$ \\
\hline Compost & $4.86 \pm 0.59$ & $2.31 \pm 0.21$ \\
\hline Dry leaves & $7.04 \pm 0.99$ & $2.95 \pm 0.20$ \\
\hline No mulch (control) & $5.43 \pm 0.74$ & $3.02 \pm 0.21$ \\
\hline White pebbles & $8.58 \pm 0.92$ & $3.34 \pm 0.28$ \\
\hline$F$ & 3.12 & 3.52 \\
\hline$P$ & 0.015 & 0.007 \\
\hline
\end{tabular}


There was a significant difference in SWC between the mulch types for Trial $2(P<0.05 ; F=3.52$; d.f. $=4.1165)$. Shrubs with compost had a significantly lower SWC than shrubs mulched with white pebbles, while no mulch, dry leaves, and bark chips had similar SWC and were not significantly different from one another (Table 4).

SWC decreased by $92.2 \%$ in Trial 1 , from $8.78 \pm 0.6 \%$ for all shrubs on Day 1, to $0.69 \pm 0.17 \%$ on the last day of the trial (Fig. 5).

For Trial 2, SC measures of shrubs decreased by $98.6 \%$ from Day $1\left(34.52 \pm 4.13 \mathrm{mmol} \cdot \mathrm{m}^{-2} \cdot \mathrm{s}^{-1}\right)$, when they were last watered, over 37 days to the last day of the trial $\left(0.49 \pm 0.26 \mathrm{mmol} \cdot \mathrm{m}^{-2} \cdot \mathrm{s}^{-1}\right)$ (Fig. 6).

An unpaired independent Student t-test showed significant differences between the trials for both SWC and SC (Table 5).

Simple linear regressions showed a significant relationship between SC and SWC (Table 6) for all mulch types and the control in Trial 1.

There was no significant relationship between SC and SWC for any of the mulch types or the control in Trial 2; however, there was a weak positive relationship for dry leaves in Trial 2 (Table 7).

\begin{tabular}{|c|c|c|}
\hline \multicolumn{3}{|c|}{$\begin{array}{l}\text { TABLE } 5 \\
\text { Two sample t-test with unequal variance results for the } \\
\text { comparison between Trials } 1 \text { and } 2 \text { for both stomatal } \\
\text { conductance }(n=234 ; \text { d.f. }=284) \text { and soil water content } \\
(n=234 ; \text { d.f. }=290) \text { for plants with no mulch (control) }\end{array}$} \\
\hline & $\begin{array}{l}\text { Stomatal conductance } \\
\left(\mathrm{mmol} \cdot \mathrm{m}^{-2} \cdot \mathrm{s}^{-1}\right)\end{array}$ & $\begin{array}{l}\text { Soil water } \\
\text { content (\%) }\end{array}$ \\
\hline Trial 1 Mean \pm SE & $39.21 \pm 2.21$ & $9.34 \pm 0.59$ \\
\hline Trial 2 Mean \pm SE & $5.43 \pm 0.74$ & $3.02 \pm 0.21$ \\
\hline$P$ & $3.23 \mathrm{E}^{-36}$ & $2.60 \mathrm{E}^{-24}$ \\
\hline$t$ & 1.65 & 1.65 \\
\hline
\end{tabular}

\section{TABLE 6}

Simple linear regressions ( $r^{2}$ and $P$ values) between stomatal conductance $\left(\mathrm{mmol} \cdot \mathrm{m}^{-2} \cdot \mathrm{s}^{-1}\right)$ and soil water content (\%) $(P<0.05 ; n=234)$ for Trial 1

\begin{tabular}{|l|c|c|}
\hline Mulch type & $\boldsymbol{r}^{2}$ & $\boldsymbol{P}$ \\
\hline Bark chips & 0.36 & $2.0 \mathrm{E}^{-15}$ \\
\hline Compost & 0.26 & $4.9 \mathrm{E}^{-12}$ \\
\hline Dry leaves & 0.25 & $9.9 \mathrm{E}^{-17}$ \\
\hline No mulch (control) & 0.29 & $4.5 \mathrm{E}^{-06}$ \\
\hline White pebbles & 0.29 & $1.3 \mathrm{E}^{-17}$ \\
\hline
\end{tabular}

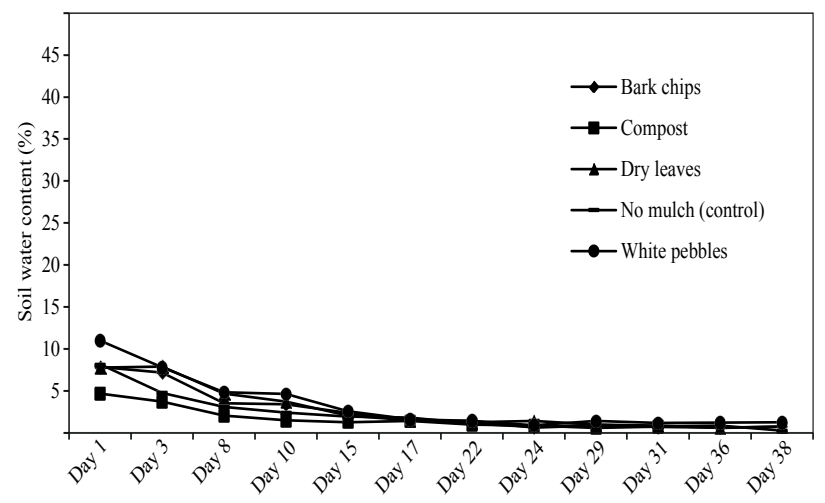

\section{Figure 5}

Soil water content over time for P. myrtifolia shrubs $(n=90)$ mulched with different types of mulch in Trial 2 (hot summer season)
The greatest loss in SWC over the trial period in Trial 1 occurred in the control plants (no mulch) (91.2\%), while the least SWC lost was in the plants mulched with compost (51.6\%) (Table 8). In Trial 2, the greatest loss in SWC occurred again in the control (94.4\%), while the smallest loss occurred in plants mulched with white pebbles (83.9\%) (Table 8).

\section{TABLE 7}

Simple linear regressions ( $r^{2}$ and $P$ values) between stomatal conductance $\left(\mathrm{mmol} \cdot \mathrm{m}^{-2} \cdot \mathrm{s}^{-1}\right)$ and soil water content (\%) $(P<0.05 ; n=234)$ for Trial 2.

\begin{tabular}{|l|c|c|}
\hline Mulch type & $\boldsymbol{r}^{2}$ & $\boldsymbol{P}$ \\
\hline Bark chips & 0.35 & 0.66 \\
\hline Compost & 0.53 & 0.74 \\
\hline Dry leaves & 0.42 & 0.06 \\
\hline No mulch (control) & 0.43 & 0.95 \\
\hline White pebbles & 0.46 & 0.33 \\
\hline
\end{tabular}

TABLE 8

Difference in soil water content percentage (\%) and stomatal conductance $\left(\mathrm{mmol} \cdot \mathrm{m}^{-2} \cdot \mathrm{s}^{-1}\right)$ in percentages between the first and last day of Trials 1 and 2 for all mulch types, and the control (no mulch)

\begin{tabular}{|l|c|c|}
\hline \multirow{2}{*}{ Mulch type } & \multicolumn{2}{|c|}{$\begin{array}{c}\text { Difference (\%) between first and last } \\
\text { day of trial }\end{array}$} \\
\cline { 2 - 3 } & $\begin{array}{c}\text { Stomatal conductance } \\
\left(\mathrm{mmol}^{-2} \mathrm{~m}^{-2} \mathrm{~s}^{-1}\right)\end{array}$ & $\begin{array}{c}\text { Soil water } \\
\text { content (\%) }\end{array}$ \\
\hline Trial 1 (cold winter season) \\
\hline Bark chips & 86.7 & 76.9 \\
\hline Compost & 50.7 & 51.6 \\
\hline Dry leaves & 90.8 & 75.1 \\
\hline No mulch (control) & 90.3 & 91.2 \\
\hline White pebbles & 85.1 & 79.6 \\
\hline Trial 2 (hot summer season) & 89.4 \\
\hline Bark chips & 99.0 & 93.1 \\
\hline Compost & 98.5 & 90.5 \\
\hline Dry leaves & 100.0 & 94.4 \\
\hline No mulch (control) & 99.2 & 83.9 \\
\hline White pebbles & 95.6 & \\
\hline
\end{tabular}

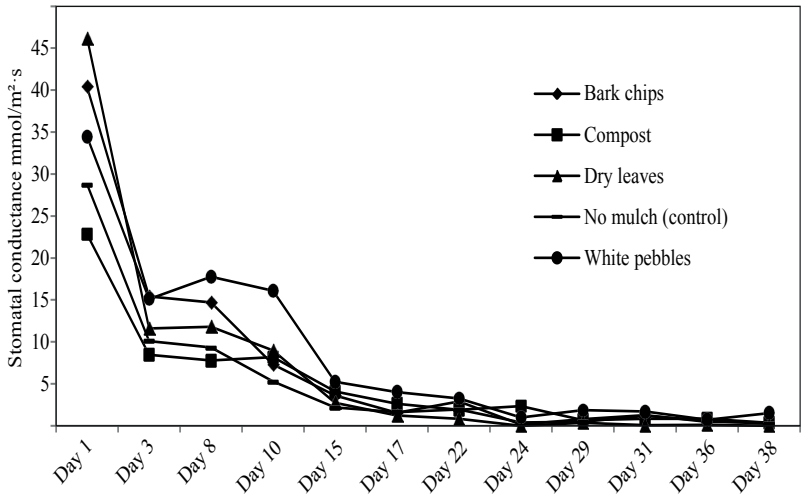

Figure 6

Stomatal conductance over time for P. myrtifolia shrubs $(n=90)$ mulched with different types of mulch in Trial 2 (hot summer season) 
By the end of Trial 1, SC had dropped the most in plants mulched with dry leaves, and the least in plants mulched with compost (Table 8 ). In Trial 2, SC decreased by $100 \%$ in plants mulched with dry leaves, while the smallest decrease occurred in plants mulched with white pebbles (Table 8).

\section{DISCUSSION}

Water use for maintenance of landscapes and gardens accounts for a large percentage of total urban water use, emphasizing the importance of reducing water loss (Zajicek and Heilman, 1991). The response of plants to water stress is complex and often modified by the presence of other stresses (Chaves et al., 2002). This research aimed to understand how the application of mulch to the soil surface of an un-watered potted shrub can affect the soil water content and potentially the plant's health, as indicated in this study by stomatal conductance.

\section{Mulch as a method of conserving soil moisture}

Mulch is instrumental in acting as erosion control with the application of vegetative matter, such as grass, leaves and prunings (Omoro and Nair, 1993). The application of mulch can be classified as an effective soil conservation practice (Smets et al., 2007).

In an analysis of tree seedling establishment in an arid environment, Zegada-Lizarazu and Berliner (2011) found that with an application of $70 \%$ mulch treatment, the optimum utilization of stored soil water and seedling development was achieved. Opinions differ regarding the amount of water conserved by mulch; Campbell (1991) reports a reduction of moisture evaporation by between 10 and $50 \%$, while other sources report a saving of up to $70 \%$ (Water Wise, n.d.). Othieno (1980) noted that mulching over tea plants in Kenya during a prolonged drought was always more effective at conserving soil moisture content than no mulch.

Results from this research show that mulch, regardless of the type or whether it is inorganic or organic, allows for significant conservation of SWC of potted shrubs in a controlled environment, as compared with the shrubs of the same species that were not mulched. SWC indicates the amount of water present in the soil (Bilskie, 2001). For this research SWC was measured as volumetric soil moisture content and expressed as a percentage between 0 and $50 \%$. For Trial 1 , after approximately 6 weeks with no irrigation, shrubs with mulch had a SWC of between $10.42 \%$ and $12.42 \%$, while shrubs with no mulch had a SWC of $9.43 \%$. For Trial 2, shrubs with no mulch had a higher SWC than with shrubs mulched with organic mulch, namely bark chips, dry leaves and compost. Cook et al. (2006) suggest that, while organic mulch such as compost will increase soil water content, it will also increase water uptake by the plant. This may explain why shrubs with bare soil had a higher SWC than organically-mulched shrubs, during Trial 2, which is the growing season. Organic mulch has been shown to enhance root growth and yield. In addition, mulch can increase the diffusion of water under the vapour pressure gradient, especially during the growing season; this means that water consumption is highest under mulch and minimum in un-mulched soil (Kumar and Dey, 2010). Shrubs mulched with white pebbles had the highest mean SWC $(3.34 \pm 0.28 \%)$. However, by the end of Trial 2 (summer season), only $7 \%$ of the plants were still alive and $50 \%$ of those were shrubs mulched with white pebbles. In comparison, by the end of Trial 1 (winter season) only $8 \%$ of the plants had died.

\section{The effect of mulch on stomatal conductance}

Stomatal conductance is a means of measuring the movement of $\mathrm{CO}_{2}$ and water vapour over the surface of a leaf (Swarthout, 2012). Studies on the photosynthesis-driven effect of water stress on stomatal conductance attribute the decrease in stomatal conductance from water stress to the reduction in photosynthesis (Wang, 2012). With slow-developing water deficits, one of the first events to take place in a plant is stomatal closure (Chaves et al., 2002).

This study used stomatal conductance as a plant health indicator as per Rahimi et al. (2013). Results for Trial 1 (winter season) showed that shrubs with mulch, regardless of the type, had significantly higher mean rates of stomatal conductance than shrubs with no mulch. For Trial 2 (summer season), shrubs mulched with pebbles had a significantly higher mean stomatal conductance than shrubs mulched with compost. Shrubs with no mulch had a slightly higher mean stomatal conductance than shrubs with compost. As per Liu et al. (2005), stomatal conductance increased slightly from Day 4 to Day 5 for shrubs mulched with bark chips, dry leaves and white pebbles, while it decreased steadily from Day 1 for shrubs mulched with compost, and shrubs with no mulch. For Trial 2, stomatal conductance decreased steadily from Day 1 , with no increase besides a slight rise between Day 3 and Day 4 for shrubs with compost. This may indicate that the stress experience by shrubs in Trial 2 was severe, possibly due to increased temperatures as a result of the season. Results may also indicate that the presence of mulch types such as bark chips, dried leaves, and white pebbles may decrease the level of water stress experienced by plants that have not been watered.

Comstock (2002) notes that perturbations such as soil drying cause a reduction in hydraulic conductance, which is required to reduce stomatal conductance in order to maintain a stable leaf water potential. Water stress causes plants to close their stomata to reduce the loss of water from the leaf, and in doing so the movement of $\mathrm{CO}_{2}$ from the boundary layer of the leaf to the sub-stomatal cavities is restricted (Warren et al., 2004), reducing stomatal conductance. Subsequently, stomatal limitations are more severe when a plant is stressed than when it is not (Farquhar and Sharkey, 1982). It can be assumed then, that mulch may contribute to the reduction in loss of soil moisture and therefore an increase in stomatal conductance. Simple linear regressions only showed a significant negative relationship between volumetric soil moisture content and stomatal conductance in Trial 1, which was conducted during the cold winter season. Schulze et al. (1973) showed that stomata of plants in a hot desert island closed with an increase in field temperature when a plant was under high water stress, independent of atmospheric humidity. Steinberg et al. (1989) also showed that water stress lowers stomatal conductance in mature leaves. Temperatures experienced in Trial 1 were significantly lower than those experienced in Trial $2(P<0.05)$ and it can be assumed that high temperatures during Trial 2 may have affected the increased closure of stomata and reduction in stomatal conductance.

\section{CONCLUSION}

This research indicates that the application of mulch can significantly reduce the loss of soil moisture from potted shrubs, and lengthen the duration of health of plants over time. Organic mulch, specifically dry leaves, proved to be most effective at conserving soil moisture under cooler, winter conditions, 
while bark chips ensure a higher rate of stomatal conductance in shrubs. This means that plants mulched with bark chips were 'healthier' for longer than plants with other mulch types, even though SWC was lower. Under hot summer conditions, mulching with white pebbles produced significantly higher soil moisture levels for longer, while compost, bark chips and dry leaves were inefficient in acting as a mulch in terms of soil moisture conservation. In other words, it is possible that the organic mulches did not provide a sufficient barrier to water loss through evaporation from the soil surface, especially during the high growth season. Plants mulched with white pebbles had the highest stomatal conductance as opposed to other mulch types.

Ambient hothouse temperature had a significant effect on both SC and SWC, with a mean decrease in both measures occurring during the hot summer season, as opposed to the cold winter season. There was also a significant positive relationship between SC and SWC during the winter trial but not during the summer trial. During the cold winter season, SC and SWC decreased congruently over time for all mulch types, which indicates that mulch type does not have a great influence on plant health and SWC conservation during the non-growing season. SC and SWC was significantly higher on average during the cold winter season, than in the hot summer season, which may indicate that mulch has a more substantial effect under cooler ambient temperatures than it does under warmer conditions.

Gardeners and landscapers can save up to $20.4 \%$ of SWC using mulch, as opposed to no mulch. The benefits of the two most successful mulch types in terms of soil water conservation and overall plant health as indicated by SC, namely, bark chips and white pebbles, need to be weighed up in comparison with their disadvantages. While bark chips improve water-holding capacity of the soil, reduce weed growth, cool the soil, and are widely available in a number of sizes and colours, bark chips can decompose relatively quickly (within 1-2 years) and can cause the removal of nutrients such as nitrogen from the soil during decomposition. In comparison, white pebble mulch does not decompose, and allows effective infiltration of water; however, it can heat up soil and does not assist with the waterholding capacity of soil (Wiese, 1999).

\section{ACKNOWLEDGEMENTS}

The authors thank Rand Water for sponsoring this research. Professor J Hendrick provided scientific support. Staff at Rand Water Environmental Management Services Nursery are thanked for their contribution to monitoring and recording results from the field trials.

\section{REFERENCES}

ACHARYA CL, HATI KM and BANDYOPADHYAY KK (2005) Mulches. In: Hillel D, Rosenzweig C, Pawlson DS, Scow KM, Sorger MJ, Sparks DL, Hatfield J (eds) Encyclopedia of Soils in the Environment. Elsevier, Amsterdam.

ADEKALU KO, OKUNADE DA and OSUNBITAN JA (2006) Compaction and mulching effects on soil loss and runoff from two southwestern Nigeria agricultural soils. Geoderma 137 (1 \& 2) 226-230. https://doi.org/10.1016/j.geoderma.2006.08.012

ALLISON FE (1973) Chapter 25 Use of mulches. In: Soil Organic Matter and its Role in Crop Production: Developments in Soil Science. Amsterdam, The Netherlands. ISBN: 0-444-4 1017-1.

ARTHUR E, CORNELIS WM, VERMANG J and DE ROCKER E (2011) Effect of compost on erodibility of loamy sand under simulated rainfall. Catena 85 (1) 67-72. https://doi.org/10.1016/j. catena.2010.12.005
ASHWORTH S and HARRISON H (1983). Evaluation of mulches for use in the home garden. HortScience 18 180-182.

ATHY ER, KEIFFER CH and STEVENS MH (2006) Effects of mulch of seedlings and soil on a closed landfill. Restoration Ecol. 14 (2) 233-241. https://doi.org/10.1111/j.1526-100X.2006.00125.x

BILSKIE K (2001) Soil Water Status: Content and Potential. Campbell Scientific, Inc., Texas, USA.

BLUM A (2011) Plant Breeding for Water-Limited Environments. Springer Publisher, New York, NY. https://doi. org/10.1007/978-1-4419-7491-4

CAMPBELL S (1991) The Mulch Book: A Complete Guide for Gardeners (Down-To-Earth Book). Storey Communications, USA. ISBN: 0-88266-659-2.

CAMPIGLIA E, MANCINELLE R, RADICETTI E and CAPORALI F (2010) Effect of cover crops and mulches on weed control and nitrogen fertilization in tomato (Lycopersicon esculentum Mill.). Crop Protect. 29 (4) 354-363. https://doi.org/10.1016/j. cropro.2009.12.001

CHAVES MM, PEREIRA JS, MAROCO J, RODRIGUES ML, RICARDO CPP, OSÓRIO ML, CARVALHO I, FARIA T, and PINHEIRO C (2002) How plants cope with water stress in the field. Photosynthesis and growth. Ann. Bot. 89 907-916. https://doi. org $/ 10.1093 / \mathrm{aob} / \mathrm{mcf} 105$

City of Johannesburg (n.d.). We're living in an urban forest. Retrieved 16 September 2014 from http://www.joburg.org.za/index. php?option=com_content\&id=355: were-living-in-an-urbanforest\&Itemid=188.

CLAYTON S (2007) Domesticated nature: motivations for gardening and perceptions of environmental impact. J. Environ. Psych. 273. https://doi.org/10.1016/j.jenvp.2007.06.001

COMSTOCK JP (2002) Hydraulic and chemical signalling in the control of stomatal conductance and transpiration. J. Exp. Bot. 53 (367) 195-200. https://doi.org/10.1093/jexbot/53.367.195

COOK HF, VALDES GSB and LEE HC (2006) Mulch effects on rainfall interception, soil physical characteristics and temperature under Zea mays L. Soil Tillage Res. 91 227-235. https://doi.org/10.1016/j. still.2005.12.007

Department of Water Affairs (2013). National Water Resource Strategy: Water for an Equitable and Sustainable Future: June 2013 Second Edition. Department of Water Affairs, Pretoria.

DURYEA ML, ENGLISH RJ and HERMANSEN LA (1999) A comparison of landscape mulches: chemical, allelopathic, and decomposition properties. J. Arboricult. 25 (2) 88-97.

FANG S, XIE B, LIU D, and LIU J (2010) Effects of mulching materials on nitrogen mineralization, nitrogen availability and polar growth on degraded agricultural soils. Int. J. Biol. Biotechnol. Manage. Afforestation Reforestation 41 (2) 147-162.

FARQUHAR GD and SHARKEY TD (1982) Stomatal conductance and photosynthesis. Annu. Rev. Plant Physiol. 33 317-345. https://doi. org/10.1146/annurev.pp.33.060182.001533

GUPTA GG (1991) Effects of mulching and fertilizer application on initial development of some tree species. For. Ecol. Manage. 44 (2-4) 211-221. https://doi.org/10.1016/0378-1127(91)90009-K

GAUR AC and MUKEHERJEE D (1980) Recycling of organic matter through mulch in relation to chemical and microbiological properties of soil and crop yields. Plant Soil 56 273-281. https://doi. org/10.1007/BF02205856

GEĄB T and KULIG B (2008) Effect of mulch and tillage system on soil porosity under wheat (Triticum aestivum). Soil Tillage Res. 99 169178. https://doi.org/10.1016/j.still.2008.02.004

HERMS D, GLEASON M, ILES J, LEWIS D, HOITINK H and HARTMAN J (2001) Using mulch in managed landscapes. In: Edwards E (ed.) Sustainable Urban Landscapes. Iowa State University. Bulletin 894, PPA-45.

HOY L (2013) Personal communication 23 February, 17 June and 19 July 2013. Mr Leslie Hoy, Environmental Management Services Department, Rand Water, Gauteng, South Africa, 2000.

KUMAR S and DEY P (2011) Effects of different mulches and irrigation methods on root growth, uptake, water-use efficiency and yield of strawberry. Sci. Hort. 127 318-324. https://doi.org/10.1016/j. scienta.2010.10.023

LIU F, ANDERSON MN, JACOBSEN S-E, and JENSEN CR (2005) Stomatal control and water use efficiency of soybean (Glycine max 
L. Merr.) during progressive soil drying. Environ. Exp. Bot. 54 (1) 33-40. https://doi.org/10.1016/j.envexpbot.2004.05.002

MACDONALD B (1986) Chapter 3: Protected propagation facilities. In: Practical Woody Plant Propagation for Nursery Growers, Volume 1. Timber Press, Hong Kong. 116. ISBN: 0-88192-062-2.

MONKS CD, MONKS DW, BASDEN T, SELDERS A, POLAND S and RAYBURN E (1997) Soil temperature, soil moisture, weed control and tomato (Lycopersicon esculentum) response to mulching. Weed Technol. 11 561-566. https://doi.org/10.1017/S0890037X00045425

MONTAGUE T, MCKENNEY C, MAURER M and WINN B (2007) Influence of irrigation volume and mulch on establishment of select shrub species. Arboricult. Urban For. 33 (3) 202-209.

MUCINA L, RUTHERFORD MC and POWRIE LW (2006) The logic of the map: Approaches and procedures. In: The Vegetation of South Africa, Lesotho and Swaziland. Strelitzia 19. South African National Biodiversity Institute, Pretoria. ISBN -13: 978-1-919976-21-1.

MULAMBA LN and LAL R (2008) Mulching effects on selected soil particles. Soil Tillage Res. 98 106-111. https://doi.org/10.1016/j. still.2007.10.011

NEIBAUER M and WASKOM R (2004) Water Conservation in and around the home. Colorado State University. URL: http://www.ext. colostate.edu/pubs/consumer/09952.html (24 November 2004).

OLASANTAN FO (1999) Effect of time of mulching on soil temperature and moisture regime and emergence, growth and yield of white yam in western Nigeria. Soil Tillage 50 215-221. https:// doi.org/10.1016/S0167-1987(98)00192-5

OMORO and NAIR (1993) Effects of mulching with multipurpose-tree prunings on soil and water run-off under semi-arid conditions in Kenya. Agroforestry 22 225-239. https://doi.org/10.1007/ BF00705236

ORTIZ-CEBALLOS AI and FRAGOSO C (2003) Earthworm population under tropical maize cultivation: the effect of mulching with velvetbean. Biol. Fertil. Soils 39 (6) 438-445.

OTHIENO CO (1980) Effects of mulches on soil water content and water status of tea plants in Kenya. Exp. Agric. 16 (3) 295-302. https://doi.org/10.1017/S0014479700011054

OTIENO FAO and OCHIENG GMM (2004) Water management tools as a means of averting a possible water scarcity in South Africa by the year 2025. Water SA 30 (5) 120-124.

PEEL MC, FINLAYSON BL and MCMAHON TA (2007) Updated world map of the Köppen-Geiger climate classification. Hydrol. Earth Syst. Sci. 11 1633-1644. https://doi.org/10.5194/ hess-11-1633-2007

QUEST (2011) Report on impact assessment of water wise initiatives at garden centres. RFP 00090/10. Prepared for Rand Water, February 2011.

RAHIMI A, SAYADI F, DASHTI H and TAJABADI POUR A (2013) Effects of water and nitrogen supply on growth, water-use efficiency and mucilage yield of isabgol (Plantago ovata Forsk). J. Soil Sci. Plant Nutr. 13 (2) 341-354. https://doi.org/10.4067/ S0718-95162013005000028

SARKAR S and SINGH SR (2007) Interactive effect of tillage depth and mulch on soil temperature, productivity and water use pattern of rainfed barley. Soil Tillage Res. 92 79-86. https://doi.org/10.1016/j. still.2006.01.014

SCHULZE RE (1997) South African Atlas of agrohydrology and -climatology. WRC Report No. TT 82/96. Water Research Commission, Pretoria.

SCHULZE ED, LANGE OL, KAPPEN L, BUSCHBOM U and EVENARI M (1973) Stomatal responses to changes in temperature at increasing water stress. Planta 23 (110) 29-42. https://doi. org/10.1007/BF00386920

SMETS T, POESEN J and KNAPEN A (2008) Spatial scale effects on the effectiveness of organic mulches in reducing soil erosion by water. Earth-Science Rev. 89 (1-2) 1-12. https://doi.org/10.1016/j. earscirev.2008.04.001

STEINBERG SL, MCFARLAND MJ and MILLER JC (1989) Effect of water stress on stomatal conductance and leaf water relations along current-year branches of peach. Aust. J. Plant Physiol. 16 (6) 549-560. https://doi.org/10.1071/PP9890549

STIGTER CJ (1984) Mulching as a traditional method of microclimate management. Arch. Meteorol. Geophys. Bioclimatol. 35 147-154. https://doi.org/10.1007/BF02269417

SWARTHOUT D (2012) Stomata. URL: http://www.eoearth.org/view/ article/156262 (Accessed 18 September 2014).

TOLK JA, HOWELL TA and EVETT SR (1999) Effect of mulch, irrigation, and soil type on water use and yield of maize. Soil Tillage Res. 50 137-147. https://doi.org/10.1016/S0167-1987(99)00011-2

TURGEON AJ (1990) Turfgrass Management. Prentice-Hall, New Jersey.

TYSON PD (1986) Climate Change and Variability in South Africa. Oxford University Press, Cape Town.

WANG S (2012) Evaluation of water stress impact on the parameter values in stomatal conductance models using tower flux measurements of a boreal aspen forest. J. Hydrometeorol. $13239-$ 254. https://doi.org/10.1175/JHM-D-11-043.1

WARREN CR, LIVINGSTON NJ and TURPIN DH (2004) Water stress decreases the transfer conductance of Douglas-fir (Pseudotsuga menziesii) seedlings. Tree Physiol. 24 971-979. https:// doi.org/10.1093/treephys/24.9.971

Water Wise Gardening (n.d.). URL: http://www.waterwise.co.za/site/ water/faq/gardening.html (Accessed 16 September 2014).

WIESE E (1999) Water conservation in the urban landscape. Rand Water, Johannesburg.

WILKINSON S and DAVIES WJ (2002) ABA-based chemical signaling: the co-ordination of responses to stress in plants. Plant Cell Environ. 25 195-210. https://doi. org/10.1046/j.0016-8025.2001.00824.x

ZAJICEK JM and HEILMAN JL (1991) Transpiration by Cape Myrtle cultivars surrounded by mulch, soil and turfgrass surfaces. HortScience 26 (9) 1207-1210.

ZEGADA-LIZARAZU W and BERLINER PR (2011) The effects of the degree of soil cover with an impervious sheet on the establishment of tree seedlings in an arid environment. New For. 42 2-17. https:// doi.org/10.1007/s11056-010-9233-9 